\title{
The Image of Bogatyrs in Yakut and Russian Folklore Texts
}

\author{
Elena V. Naumova* \\ M.K. Ammosov North-Eastern Federal University \\ 58 Belinsky Str., Yakutsk, 677000, Russia
}

Received 19.02.2018, received in revised form 13.04.2018, accepted 26.04.2018

\begin{abstract}
Nearly all the developed world cultures have their own written or oral works of art which were created by the people, representatives of a certain nation. These records may or may not have been publicly acknowledged for various individual reasons. However, in some cases, these oral works of art reached us due to the fact that they were reproduced and recorded in a written form. This way, anyone who wishes to learn about the folklore of a certain national group can do so, especially nowadays when many of these fine works of art had been translated from the source language to various target languages. The present article focuses on a literary analysis of the profound characters of Russian and Yakut folklore to see if and in what aspects do the notions they imply coincide linguistically, semantically and ideologically.
\end{abstract}

Keywords: folklore, Russian bylinas, Yakut olonkho, bogatyrs, traditions, antagonists, protagonists.

DOI: 10.17516/1997-1370-0295.

Research area: linguistics, culturology.

\section{Introduction}

World culture has been developing throughout the centuries. While there may be different cultural representations of various phenomena in everyday life, there are undoubtedly similar features that can be found in seemingly different cultural realia. This can be a result of diverse events and characteristics, such as geographical position, military contacts, etc. The present study provides a theoretical overview on the notion of folklore, the history and features of bylinas and olonkho, and most importantly, how these features are reflected in the images of the protagonist and antagonist characters portrayed in the plot. Such topics serve as an important and valuable source of knowledge in the age of globalization, when specific world cultures are losing their traditional features in the world of today. It is equally important not only to sustain this knowledge but also to pass it on to other generations.

\section{Folklore: its origin, genres and representations}

Folklore as a variety of cultural representation is represented by a number of genres of oral and written works of art. The term folklore was first introduced by W.J. Thoms, an English scholar, who defined it as "the knowledge or wisdom of the people" (Anikin, 2004). Regardless the form

(C) Siberian Federal University. All rights reserved

* Corresponding author E-mail address: elv_naumova@mail.ru 
of representation (oral or written), folklore serves to express ideas which are native to the people that they describe. Folklore is commonly used to describe the following concepts: a) the origin, nature and functioning of the Universe and all its creations; b) the world of the supernatural forces, deities, and their interaction with human beings; c) the notion of wisdom of the natural and supernatural forces; d) the notion of heroism (or might), beauty and moral values in the society and antagonism with its villains and negative qualities, including sense of humor, grotesque, pure evil, and the social non-acceptance (Putilov, 1994: 15). It presents a series of fictional or semi-fictional characters and events which most commonly unfold in an imaginary place or a place that exists in the real world.

Anikin (2004) gives the following definition of folklore: "a compilation of oral works of art, traditional in their form and content, with intended or non-intended literary features, which reflect the people's everyday life, created and recreated throughout generations". The scholar (Anikin, 2004) also notes that the first written records of Russian folklore were created in the $17-18^{\text {th }}$ centuries, but it is only in the $19^{\text {th }}$ century that people began to compile them into systematic collections.

Regardless the terminological variations in its definition, folklore is a product of culture and the latter occurred as a result of human evolution, to be more precise, as soon as the human beings began using their imagination to explain various phenomena and events taking place in the world surroundings which they could not yet interpret from an empirical point of view in the early stages of evolution and social development.

The earliest record of Slavic folklore dates back to the times of the East Slavic peoples' settlement along the borderline of modern-day Ukraine and the southern part of modern-day Russia. It was a chronicle which represents a semi-fictional story of how the East Slavic tribes settled in that area. Another historical chronicle gave an explanation as to how the modern-day Kiev was founded by three brothers - Kiy, Shek, Horiv who were helped by their sister - Lybed (Anikin, 2004: 25). These chronicles reflect the customs, traditions, and way of life of the Slavic tribes at the earliest stage of their settlement.

An important feature of Russian folklore, in general, and for the present study in particular, is the establishment of mythology in the times of Ancient Rus'. Written records of that time contain sufficient evidence of paganism among the people of that time-period. People believed in and cherished the power of the natural elements and phenomena (fire, water, wind, earth) along with the wildlife. From their perspective, "the world was inhabited by imaginary supernatural creatures - domovoi ${ }^{2}$, leshii ${ }^{3}$, vodyanoy ${ }^{4}$, and mermaids" (Anikin, 2004: 27).

Even after the acceptance of Christianity, the early folklore writers of the Ancient Rus' period retained their traditional world outlook and mentioned the names of deities that were praised by the Slavic people in their folklore texts. Thus, there was a certain dual belief among the people of that time in both - the supernatural forces and in the existence of deities. This aspect of Russian folklore traditions affected the content of its subgenres and it will be closely analyzed in the subsection of the present article devoted to the images of Russian bogatyrs. Such was the initial stage of folklore developing as a genre in the Slavic cultural tradition.

The second stage of folklore development included works of art and subgenres which were not very closely linked to the religious or any kind of rituals or traditional customs (Anikin, 2004: 39). The following forms of folklore were developing in that time-period: proverbs and sayings, superstitious beliefs, and tales. At this stage of its development, Slavic folklore retained 
its duality in terms of the characters introduced in the plots and the general philosophical and religious beliefs of the people. These were the written forms of folklore and they reflected the general world view of the Slavic people. The other group of folklore subgenres of that time-period comprised of oral forms of art, specifically the following: legends, urban legends, short bylinas, and myths.

The main focus of study in the present article are the Russian bylinas (or heroic epic poems(songs)) as a special subgenre of Russian folklore, on the one hand, and Yakut heroic epic olonkho, on the other hand. Both of these subgenres portray the images of bogatyrs, which serve as the main focus of the present literary overview and analysis.

\section{A brief history of Russian bylinas and their features}

Before giving a description of the features, it is necessary to take a closer look at what various scholars understood by the notion under study. The term bylina was introduced by I.P. Sakharov in the first half of the $19^{\text {th }}$ century; this definition was chosen owing to the fact that this notion appeared in The Tale of the Armament of Igor ${ }^{5}$, which dates back to 1195, as part of an expression "the bylinas (events) of that time"(Anikin, 2004: 301) similar to the English expression"once upon a time".

As Vladimir Propp (1974) mentions in his Theory and History of Folklore, "Epic poetry is not defined by any one feature that at once determines its nature... The most important feature of epic poetry is the heroic character of its content" (Propp, 1974: 149). Epic poetry normally depicts a character that the other characters in the plot see as a hero. They regard this character as a hero not because of the appearance but for his good deeds and values. The general idea behind each Russian bylina is that a protagonist (usually a warrior) goes through a series of battles and struggles his way through to reach a certain goal. Most commonly, a mission is completed for the greater good of the native land and the people (Propp, 1974). However, the most important feature of bylinas is that they are not just simple narratives. They are usually presented in the form of poetry. Moreover, they are also meant to be performed in the form of a heroic song, though it is not sung but chanted. The musical structure of bylinas is what makes it stand out among other Russian literary genres and it is precisely what makes it heroic poetry. Epic poetry also expresses ideal heroes living in an ideal reality (Propp, 1974). Not all bylinas exist in the form of songs. Some of them are presented as prose or as fairytales with fictional characters such as bogatyrs (or warriors). These literary works date back to the $17^{\text {th }}$ century. Another important feature of bylinas is that they were initially told by the people and told and passed on from person to person, from generation to generation.

Anikin (2004) states that "there is no specific time period from which bylinas originate, however, many scholars share the opinion that they may have occurred sometime around the $10-11^{\text {th }}$ centuries... By the $13^{\text {th }}$ century, bylinas attained their typical and specific genre features". According to the scholar, the peak of bylinas' existence and flourishing as a genre was marked in the $16-17^{\text {th }}$ centuries; the genre seized to develop by the middle of the $20^{\text {th }}$ century.

$\mathrm{He}$ also states that "heroic bylinas represent several cultural aspects at once - the traces of mythological traditions of the past and the explicit display of a codex of ideal social behavior all combined into an engaging storyline and immense imagination" (Anikin, 2004: 40).

Generally, the scholar defines bylinas as follows: "heroic songs, which appeared as a form of expressing the people's historical world view in the East Slavic period, and which developed in 
the times of Ancient Rus'; the literary intention of this genre is to praise the traditional idealistic features and standards; they also reflect the historical facts using the language of imagery and combining fictional facts with non-fictional ones, at the same time they are organized in a poetic structure which contributes to the uplifting and praising, patriotic and heroic tone of the unfolding plotline" (Anikin, 2004: 303).

Dixon-Kennedy (1998) gives the following definition of bylinas: "(Russ. pl. byliny; from byl', meaning "fact" or "true story"). One of the three categories of Russian legend, with the skazka6 and the bylichka7. The byliny, or stariny, tell of the heroes of yore... and of their daring deeds in battle against the enemies of ancient Russia".

By the beginning of the $21^{\text {st }}$ century, a number of writers (A. Kaspari (1894), G. Karnaukhova (2003), M.S. Krukova (1937), P.I. Ryabin-Andreev (1940) etc.) compiled a selection of bylinas and folktales putting them into both - poetic and prose form. The given research is based on the bylinas presented by Galina Karnaukhova (2003) in a book series titled Russian Bogatyrs.

\section{A brief history of compiling Yakut olonkho and its special features}

Undoubtedly, the importance of olonkho in the scope of world literature is immense. Not only is it a unique representation of the Yakut traditional folklore but it is also a reflection of the moral values and culture of the Yakut people. On November 25, 2005, UNESCO proclaimed olonkho a masterpiece of oral and intangible heritage of humanity.

In its literary essence, the Yakut olonkho is similar to the Russian bylinas. It is also presented in the form of epic poetry about a hero or a number of heroes that set off on a journey to fight against evil forces and serve for the greater good. However, the imaginary world of olonkho is more complex than that of the Russian bylinas. Before giving a detailed description of how this world is organized, it is essential to examine the origins of folklore studies in Yakutia and the first olonkho researchers in terms of their outlook on various aspects of olonkho studies.

The first attempts to compile and study olonkhoweremadeby N.S. Gorokhov, whoworked in a close partnership with I.A. Khudyakov; both of them shared a common scientific interest in Yakut folklore. I.A. Khudayakov collected and then translated a number of olonkho texts, such as "Khaan Djargystay", a story telling about three generations of bogatyrs and several other short olonkho stories, which were included into the Yakut Traditional Literature Series published by E.K. Pekarsky (Illarionov, 2016: 22).

A further contribution into the preservation of Yakut traditional literary works of art was made by P.A. Oyunsky, "a distinguished social and political worker, and one the first educated scientists among the Yakut people" (Illarionov, 2016: 31). He compiled a large collection of olonkho, mainly from the Zhuleisky nasleg ${ }^{8}$ of the Tattinsky region of Yakutia, which was his native land. This district is said to be the birthplace of many distinguished olonkhosuts of Yakutia. They predominantly told olonkho about Nurgun Botur the Swift, one of the most prominent bogatyrs in the universe of olonkho.

It was G.U. Ergis (Germogenov) who founded the Yakut school of folklore studies in Yakutia. In his book Historical Tales and Legends of the Yakuts, G.U. Ergis classified these legends and tales into the following categories, according to their content: 1) the arrival of the Yakut people to the Lena River from the south direction; 2) other tribes; 3) the times of kyrgys ujete[kir'giz] [juje'te] (the time of wars/battles/ troubles); 4) the Yakuts' settlement in the Vilyuysky and Kobyaysky regions; 5) Yakutia becomes an administrative subdivision of Russia; 
6) the Yakuts' settlement in the northern parts of Yakutia; 7) descendants from simple families; 8) legends and tales about everyday life; 9) images of wealthy representatives of the society who oppress the lower class. This classification gives a full representation of the Yakut traditional life and customs (Illarionov, 2016: 57).

A comparative approach to the study of olonkho was initiated by another distinguished scholar of Yakutia - I.V. Pukhov. He published a series of works devoted to a comparative analysis of Yakut olonkho and a heroic epic of the TurkicMongol peoples. A brief overview of his works includes: Yakut olonkho and Altaic epic, Yakut olonkho and the Kalmyk Zhangar, Geser and olonkho, etc. (Illarionov, 2016: 68). From this point in the history of Yakut folklore studies, olonkho was recognized and classified as a heroic epic in terms of its genre. Thus, starting from the preRevolutionary years, there have been successful attempts to not only create a collection and a compilation of olonkho from various regions of Yakutia, but it also became a subject of in-depth scientific study among the local scholars, hence promoting the preservation and popularization of this intangible and valuable work of art.

What is olonkho, how and in what form is it presented? It is a large literary work of art (poetry) comprising of seven to ten thousand lines. Some olonkho may be even larger in length (Illarionov, 2016: 99). The same scholar also notes that the performers of olonkho (known as and referred to as olonkhosuts) defined the length of olonkho pieces by the duration of the storytelling process. Most commonly 24 hours time range serves as the unit of olonkho length measurement. If the olonkho was presented at a large feast, it could last for two or three nights (Illarionov, 2016: 99).

Though it belongs to the large scope of folklore, it is different from other types of oral art in the sense that it is more traditional in terms of its plot and compositional structure. Normally, an olonkho unravels with an introduction which is typical of an epic genre; this is followed by a detailed description of the three worlds, the Holy Tree called Aal Luk Mas, the characters' households, a description of the main character, his armor and his riches along with some other details relevant to the plot line (Illarionov, 2016: 100). I.V. Pukhov (1962) singles out the four following main types of motifs which serve as the starting point for the Yakut bogatyrs: 1) an (evil/demon) bogatyr attacks a family belonging to the Aiyy (Gods) tribe; 2) an Abaahy (demon/ antagonist) bogatyr attacks the main character's family; 3) the main character (hero/protagonist) sets off on a journey to find a bride; 4) the main characters sets off in search for adventures. Traditionally, each olonkho contains a description of a bogatyr battle scene or their journey.

Olonkho differs from other oral art genres in the manner or style of its performance. The descriptive excerpts are read at a fast speed, meanwhile the characters' monologues are presented in the form of a song, which contributes to the characters' image (Illarionov, 2016: 101).

The term olonkho itself is used to refer not only to the genre it represents, but to the various tales told within this genre. The titles of these tales normally coincide with the names of the main characters involved in the plot, for instance, Nurgun Botur the Swift, Er Sogotokh, Urung Uolan, Muldju the Mighty, etc. (Illarionov, 2016: 101).

The Yakut olonkho is normally told by a specific author or olonkhosut (olonkho storyteller) in the form of a song or a chant. There are male and female olonkhosuts. The olonkhosut performs his epic song as though he/she is in the world of olonkho $\mathrm{him} /$ herself, as though he/she saw and witnessed everything with his/her own eyes. This technique helps the listeners to immerse themselves into the magical atmosphere of olonkho.

The manner in which a particular olonkho is told or sung can be different depending not only 
on the gender of the storytellers but also on the region where they come from. This particular research focuses on the literary analysis of the heroes presented in the two short olonkho Ogo Tulaaiakh Warrior by V.O. Karataev, a famous Yakut olonkhosut, and Kyys Kylaabynai the Warrior by another famous olonkhosut, D.A. Tomskaya.

V.O. Karataev was one of the most talented olonkhosuts of the previous generation. According to his own stories and recollections, he was brought up among narrators. Starting from his early childhood, he listened to performances of talented olonkhosuts and thus became familiar with it. He originally comes from the Vilyuysky district of Yakutia, where the performances of olonkho were widely spread. Illarionov (2006) states that one of the most famous olonkho performed by V.O. Karataev was about the adventures of Er Sogotokh.

Daria A. Tomskaya comes from the Verkhoyansky district of Yakutia. She also comes from a family of olonkho writers. The Verkhoyansky region olonkho performance has the following unique features: it is presented in a spoken form similar to that of everyday speech, it is narrated in a poetic manner and it is sung. Singing is used when characters talk to other characters and represents direct speech (Nikiforova, 2011). Narrative speech is commonly used in the description of certain events, things and characters. Spoken form is used to show the development of the plotline, for example, dialogs, characters talking to themselves, as well as explanations of specific words to the audience (allusions, obsolete, and dialect words).

\section{The notion of a bogatyr:}

\section{etymology and cultural representation}

The word bogatyr is present in both, Russian and Yakut folklores. Before giving a literary analysis of the represented characters, referred to as bogatyrs, it is essentially important to observe whether they reflect the same concepts from a strictly linguistic and etymological point of view.

The word bogatyr is represented in a number of Slavic and Turkic languages. Originally, it comes from the Old Turkic language (Fasmer, 1986):

Old Turk. bayatur 'brave, military leader' > Turk. batur, Shor. payattyr 'hero', Mon. bagatur, Kalm. bātr; Rus. bogatyr, Ukr. bogatir, bagatir, Old Rus. bogatyr, Pol. bohater, bohatyr, Bul. bagatyr, DunaiBul. $\beta \alpha \gamma \dot{\alpha} \tau o v \rho<$ bogatiy 'rich'.

In his Encyclopedia of Russian and Slavic Myth and Legend, M. Dixon-Kennedy (1998) gives the following definition of the notion under study:

"Bogatyr'9(pl. bogatyri) a "Champion", the postChristian Russian name for a knight of Holy Russia. These knights were revered by the folk as demigods who fought imps, demons, and other evil beings sent forth by the Devil" (Dixon-Kennedy, 1998: 39).

The Yakut language belongs to the Turkic languages family and the word bogatyr is also used in the Yakut language. The following variants are represented in the Yakut olonkho: bootur [bo:'tur] (in reference to one of the main olonkho characters Nurgun Botur the Swift from the olonkho, written by Oyunsky (1982), where the title coincides with the name of the main character. Other examples include the word bootur in Petr Ogotoev's olonkho about Eles Bootur; and the representations in the Yakut olonkho analyzed in the present study are as follows: buhatyyr ${ }^{10}$. These notions in the Yakut language are interpreted as "a noble, mighty and brave warrior". 


\section{Features of bogatyrs in Russian folklore}

Russian bylinas normally depict warriors known in the Russian language and culture as bogatyrs. There is an entire range of such heroes in different bylinas. Three of the bogatyrs are considered to portray a classic image of a bogatyr and they are referred to as "classic bogatyrs". They are: Ilia Muromets (one of the holy bogatyrs), Dobrynya Nikitich, and Alyosha Popovich.

Ilia Muromets is considered to be the main bogatyr in the trinity of the ones mentioned earlier, due to the fact that he had done the largest amount of great deeds out of the three bogatyrs; he is the only one of the trinity who can beat all the enemies single-handedly. In his Dictionary of Mythology, E.M. Meletinsky (1990) writes that "Ilia Muromets is mostly referred to as "old" and depicted as an old man with grey hair and beard sitting on a white horse". This representation signifies the fact that he is the wisest and the most experienced of them all. According to one of the earliest bylinas devoted to him called How Ilia from Murom became a bogatyr, he came from a family of peasants and he was crippled from his early childhood ("he couldn't lift his hands and arms") but one day, two wanderers came by his parents' house and asked him to help them ("to open the doors"); at first, he refused to do so but they asked again, and this time he "jumped up to his feet" and opened the doors. These wanderers gave him some magic potion and asked him to drink some spring water. The more spring water he drank, the stronger he became. Thus, he became a mighty bogatyr. This is a significant feature of most Russian bogatyrs - they gain their power and strength from Mother Nature in its various forms (water, earth, etc.). In one of the bylinas another mighty bogatyr (Svyatogor) passes on his powers to Ilia making him even stronger than before. However, at some point in his life, Ilia Muromets dies and turns into stone in one of the caves. After his death, he became known as Saint Ilia, or the God of Thunder (on the analogy with Zeus, the ancient Greek god, or, Thor, the ancient Scandinavian god of thunder) and in some other Slavic variations of the myths about this bogatyr. The fact that he came from a peasant family serves as an explanation as to why he is also considered to be the god of harvest in some Slavic myths.

Interestingly Dixon-Kennedy (1998) refers to Ilia Muromets as "a Russian knight, or bogatyr". Therefore, the notion knight is also applicable to this particular bogatyr. Ilia Muromets is also known as a religious bogatyr due to the fact that he made a vow to God not to spill blood and then asked God for permission to break this vow so that he could protect the innocent people from the enemy forces.

This is how Ilia Muromets and his strength is described in one of the first bylinas devoted to him:

"Ilia went to fetch some water [from a well], but the earth would not hold him; his feet sunk into the ground like into a bog; he tried to cling on to an oak tree but ripped it out together with the roots. The chain from the well broke like a string. Ilia takes careful steps [in the house], but the floorboards break under his feet. He speaks in a whisper, but the door breaks off the hinges" (Karnaukhova, 2003: 38).

Meletinsky (1990) writes that "Dobryna Nikitichis is the second strongest bogatyr in the trinity of the mightiest bogatyrs in Russian bylinas". Unlike Ilia Muromets and Alyosha Popovich, Dobryna Nikitich is depicted as a warrior in the pure sense of the word. He is also prominently an educated bogatyr among the other two bogatyrs. He could play on a Russian traditional music instrument (gusli ${ }^{11}$ ), sing, and play chess (a skill that helped him beat the Tatar Khan). He also has the closest relationship bonds 
with the tsar Vladimir and he is sometimes referred to as his nephew.

In one of the first bylinas about him, Dobryna Nikitich is described in the following way:

"The entire Kiev knew about Dobrynya: he is tall, stout, educated, brave in battle and outgoing during feasts. He can sing a song, play the gusli, and say a few wise words. He is also calm and gentle when it comes to his temper. He will not scold anyone and will not hurt anyone for no reason. That is why people call him 'the quiet Dobrynushka"' (Karnaukhova, 2003: 27).

Alyosha Popovich, the third bogatyr from the main trinity of bogatyrs, represents one of the most controversial images of a bogatyr in Russian bylinas (Meletinsky, 1990: 34). He is the son of a priest and he is known to be weaker in strength compared to the Ilia Muromets and Dobrynya Nikitich. However, he is witty, dexterous, resourceful, and brave. Along with these positive characteristics, he also has negative ones, which make him stand out from the other two bogatyrs and brings him closer to the chthonic characters in Russian mythology. Thus, Alyosha Popovich could also be cunning, boastful, his jokes can sometimes be cruel and he can also lie to others for his own benefit (like he did in one of the bylinas when talking to Dobrynya Nikitich). All these aspects make his character dual by nature. Nevertheless, his good qualities outweigh the negative ones.

This is how Alyosha Popovich is depicted in one of the bylinas:

"Never shall I let some evil creature cross my path! If I cannot take it down with might, I will beat it with my wit. Dear stranger, old fellow, lend me your dress for a while, and take my bogatyr clothes. Help me beat Tugarin" (Karnaukhova, 2003: 24).

This is how Ilia Muromets talks about Alyosha Popovich in one of the bylinas:
"No offense to Alyosha, but he is the son of a priest, his eyes are full of greed and his fingers are sticky ${ }^{12}$. If Alyosha sees a lot of gold and silver, he will want to take it and will die purposelessly" (Karnaukhova, 2003: 52)

Some other bogatyrs featured in the bylinas are: Volga (or Volkh) Vseslavyevich, who, apart from the standard bogatyr powers, has animorphic abilities, which he inherited from his father, an ancient dragon referred to as Zmei in Russian mythology (Meletinsky, 1990: 120). Due to these special abilities Volga has some features typical of chthonic characters. $\mathrm{He}$ is often associated with Veles (or Volos), the Slavic god of cattle, domestic animals or the god of prosperity because of his magic animorphic abilities (Meletinsky, 1990: 120).

Mikula Selyaninovich is depicted as a farmer bogatyr with supernatural powers that he gains from the Mother Earth. The image of this bogatyr represents the Slavic tradition of praising and cherishing peasant labor (Meletinsky, 1990: 358).

Svyatogor is perhaps the only bogatyr with more or less useless special abilities. According to the bylina, he is a giant so heavy that even the Mother Earth could not carry him. He lives in the mountains, hence, the name Svyatogor (lit. Rus.: svyat - holy; gor - mountain). This aspect brings forth his chthonic features; to be more precise, the fact that he is always literally attached to the ground and rocky areas, he even meets his death in a coffin made of rock that appears to fit his gigantic size (Meletinsky, 1990: 481). In other words, unlike the other bogatyrs, he is linked closer to the Under World (represented by the ground). Apart from this, Svyatogor tends to be boastful, which is undoubtedly a negative feature. In some versions of bylinas devoted to him, he is referred to as Gorynich, who is a chthonic character. 
Seemingly patriarchal, nevertheless, there is also a female bogatyr featured in the bylinas. She is Vasilisa Mikulishna, the daughter of Mikula Selyaninovich, one of the strongest bogatyrs.

All the bogatyrs have a large scope of common features along with some differentiating ones (Table 1). Generally, they look no different from ordinary human beings but their image is hyperbolized to a super-human, i.e., the majority of them are gigantic in size; they have super strength, super vision, and other super powers. They can shape-shift or turn into birds and animals. Most of them are witty, wise, patriotic, romantic, selfless protagonists and defenders of the Russian land. Most importantly, they gain their strength from the earth, or from the Mother Land or the Russian Land as they like to call it. They ask for nothing in return, although the Russian tsar always finds a way to reward them for their great deeds and they usually serve at his court as the noble and main defenders of the land.

The Russian bogatyrs do not fight against ordinary people. They usually battle against supernatural or super strong forces, which are either almost as equally strong and powerful as they are, or can only be beaten by them, i.e., no ordinary human can beat them in battle. Thus, Russian bylinas also feature antagonistic or chthonic bogatyrs, they are also creatures with supernatural powers) that are metaphorically represented by the opponents that Rus' had to face in the course of its past history, such as: Tugarin Zmei, a chthonic character, which resembles a fire-breathing dragon-like creature that battled with Alyosha Popovich and that the latter managed to slay. Tugarin Zmei represents a Polovets ${ }^{13}$ Khan Tugorkhan who unsuccessfully tried to invade the Russian land in the 11 $11^{\text {th }}$ century (Meletinsky, 1990: 540). Solovei Razboinik, a chthonic character with animorphic abilities and the ability to let out a deadening whistle. He resembles a bird, hence the name Solovei (Rus. lit.: 'nightingale') His last name, Razboinik (Rus. lit.: robber, villain, bandit) reflects his antagonistic nature. Zmei Gorynich is another chthonic and antagonistic image of a dragon-like creature with at least three heads. Its special feature is that it inhabits both the sky and earth; it can fly and it has a secret hideout down in the caves, where it keeps innocent creatures as captives, princesses, for instance (Meletinsky, 1990: 220).

These are all allegorical images of the countries and their rulers who tried to conquer the Russian land in a series of unsuccessful attempts. According to these bylinas, the enemy did not succeed due to the qualities that the Russian people possess. These psychological and national

Table 1 . The bogatyr features can be summarized as follows

\begin{tabular}{|l|l|l|}
\hline Bogatyr & Physical features & Personal qualities/traits \\
\hline $\begin{array}{l}\text { Volga Vseslavyevich, } \\
\text { Ilia Muromets }\end{array}$ & $\begin{array}{l}\text { Super strength, super growth (he grew up } \\
\text { hour by hour), shape shifting (he can turn } \\
\text { into birds and animals), super speed }\end{array}$ & $\begin{array}{l}\text { Bravery, wittiness, kindness, benevolence, } \\
\text { fairness, righteous anger (when someone } \\
\text { is being unfair, or wants to attack his } \\
\text { Motherland or doesn't want to/is afraid of } \\
\text { protecting the Motherland together with } \\
\text { him) }\end{array}$ \\
\hline Mikula Selyaninovich & Super strength & $\begin{array}{l}\text { Kindness (more than in other bogatyrs), } \\
\text { wit, bravery, benevolence }\end{array}$ \\
\hline Svyatogor & Super strength, super weight, & Wit, bravery \\
\hline Dobrynya Nikitich & Super strength, super speed & Wit, bravery, kindness, fairness \\
\hline Alyosha Popovich & Dexterity & \\
\hline Vasilisa Mikulishna & Super strength, super speed &
\end{tabular}


features are all hyperbolized and reflected in the images of the bogatyrs.

\section{Features of Yakut bogatyrs in olonkho}

Before conducting a closer study of this aspect is it necessary to attain an understanding of how the world in the Yakut epic is structured.

The universe in the Yakut olonkho is subdivided into three worlds: the Upper World (inhabited by the good deities and spirits), the Middle World (inhabited by the local people the Yakuts or Urankhai ${ }^{14}$ Sakha, who form a large tribe referred to in the olonkho as the Aiyy aymaga $a^{15}$ ) and the Under World (inhabited by the evil spirits known as Abaahy $\left.{ }^{16}\right)$. Interestingly, these creatures may sometimes inhabit the Upper World (Illarionov, 2016: 202).

The main characters (warriors/heroes referred to as bogatyrs) of the plot live in the Middle World more commonly known as the world where people live or the human world. The main characters, who are Yakut versions of bogatyrs, fight against the forces of evil to protect their family and their loved ones from any harm that might be caused by the creatures from the Under World who occasionally appear and reappear to intervene into the quiet and peaceful life of the main characters and their family.

Illarionov (2016) states that olonkho has a fixed system of characters who are represented in nearly all the olonkho series. There is a main character - male or female bogatyr from the Aiyy aymaga tribe. As has already been mentioned above, the mission of this protagonist is to, first of all, ensure the peace and safety on the planet, as well as to create a family and continue their ancestry.

Perhaps, one of the most important characteristic and distinctive features of the Yakut main characters is that they represent the ancestors, the forefathers and foremothers of the
Yakut people, i.e., the Yakut people originate from these characters.

A brief overview of the system of characters from the Yakut olokho analyzed in the present study revealed the following characteristic features.

First of all, just like in the Russian bylinas, there is a female bogatyr character along with a traditional male bogatyr character. However, while the Russian system of characters (both protagonists and antagonists) is predominantly patriarchal (only one female bogatyr is explicitly mentioned in one of the bylinas), the Yakut system of characters contains a vast range of prominent female characters, whether they are bogatyrs or not.

In the olonkho about Ogo Tulaaiakh bogatyr, the olonkhosut tells the listeners/readers about the unusual origin of the main character (Karataev, 2017: 172):

Not a single man of wealth//Was born there.//Suddenly, I saw that//In this Primordial Motherland//At the bottom of that birch-tree//A naked boy was lying.//If this poor boy//Fell down from the Upper World,//He would be covered with frost and icicles,//If he flew up from the Under World,//He would be covered in dust and mud,//If he came here, walking from//The Middle World,//He would have left traces.

Traditionally, in the olonkho the main bogatyr characters are born (appear) as though out of thin air. They usually do not know where they came from or who their parents are (Karataev, 2017: 172):

The boy stood up,//Went around in circles,//Looked here and there,//But did not find//Anybody with two legs//Or any living creature around,//So, wondering// Who he was//And where he was from,//He walked around the place,//Back and forth across//His alaas ebeh khotun. 
This is a feature that distinguishes them from the Russian bogatyrs who traditionally have a family and know where they come from. This feature is reflected in the names of the Russian bogatyrs, e.g., Ilia Muromets (Ilia from Murom (a city in Russia), Alyosha Popovich (Rus. lit. the son of a priest).

The Yakut bogatyr's name literally means "an orphan child" (ogo 'child', tulaaiakh 'orphan').

Despite this fact, the bogatyr in Yakut olonkho also possesses superpowers, such as super-speed growth and super strength (Karataev, 2017: 172):

The boy//In one day - became one-year-old,//n two days - two-years old,//n three days - three-yearsold,//That was how he grew fast,//That was how he sprang rapidly.//As boy gradually grew up,//He torn out larch trees//Of medium size//As though it was grass,//He cut hacked larches//As though it was weed.

An Abaahy creature in the form of large two or three headed eagle comes to the bogatyr and not only tells him that he is a worthy representative of his kind that has the ability to protect his Aiyy tribe but also warns him not to battle with the creature's father, Buor Burghaljin Toyon (Yakut. Lit.: 'Heavy Rock Lord') a reference to the chthonic image of the Lord of the Under World. The animalistic feature of the protagonists and antagonists is something that both folklores under study have in common.

Just like the Russian bogatyrs, the Yakut bogatyr attains more strength and might from other magical creatures and objects. In this case, he receives a horse, which later becomes a bogatyr horse (similar motif to the one in the bylina about Ilia Muromets) and white shaman girl (in the form of a crane) descends from the Upper World (as she says so herself) and gives him more strength (Karataev, 2017: 179):
I was sent for you//From Aiyy who live high above.// The sent me with blessings//So that your bones//Will become unbreakable,//Your setelekh ${ }^{17}$ - untearable,// Your blood - invincible.//Open your mouth quickly!// Hurry! - she said so//And threw something//The size of a male partridge,//When our dear boy//Crunched it and swallowed,//He suddenly became ten times bigger//Than he was before,//He became all swollen up//And his breast//Widened and broadened//Like a huge barrel,//His muscles and sinew//Began flexing// Like pickerels.

The main character also retains the animorphic feature that manifests itself later in the olonkho as the plot unfolds (Karataev, 2017: 207):

He has smashing fists,//So, such a man like you//Does not have//Any chances.//That is why//I am giving you// My black silver scarf//Form my left ear,//You turn into a shrew mouse.

Sometimes, the main character is helped by the forces of nature, which appear in an anthropomorphic form. For instance, the bogatyr was helped by three other bogatyrs sent from up above who resembled the element of fire or the spirit of the household (Karataev, 2017: 189):

Before his shout//Reached the top of the vast high sky,//The boundless sky//All covered with spots,//As though sprinkled with thick kumis ${ }^{18}, / /$ Then it covered// With black speckles//That were like red copper pots// Put upside down,//And the huge roaring whirlwind// Followed by eight lightning//Fell down,//The furious whirlwind//Of four alarms//Blew out, whirling up everything on its way,//It was the great warriors//Of the three Upper Worlds,//Uot Dugui ${ }^{19}$ the Warriors// That came down from above.

The image of the chthonic forces referred to as Abaahy is similar to the representation of such 
evil forces in Russian bylinas as Zmei Gorynich (Karataev, 2017: 189):

A giant of Abaahy came in.//He had not ever seen//In his life//And in a whole century//Such a huge Abaahy like him.//He had three heads,// The middle of them//Was all made of iron,//Not a single piece of flesh was seen on his body,//It was all covered with armor//As hard as stones.

The olonkho titled Kyys Kylaabynai ${ }^{20}$ the Warrior, features a female main character. Just like in the previously mentioned olonkho, the female bogatyr does not know who she is or where she is from. She has a younger sister, who does not have any bogatyr features (Tomskaya, 2016: 171):

Once they were sleeping... When the girls came to their senses, they did not remember where they were from.

Just like the male characters in the Russian and Yakut folklore, this female character has superpowers, for instance, super speed (Tomskaya, 2016: 180):

The girl went outside and ran to the east. Wind whistled in both her ears like a golden eye's wing.

Along with the superpowers mentioned earlier, she also has animorphic powers (Tomskaya, 2016: 184):

The last was the elk skin bag. It was lying on the first bench. The girl loosened the ropes and turned the dog skin inside out. A four-eyed puppy jumped out of the bag.

This is how the author of this olonkho depicts the chthonic image of the Abaahy force (Tomskaya, 2016: 213):
He had a long blue tongue. As for his teeth, he had rare crooked fangs reminiscent of rubble ice. As for his hair, it stuck out in three tutum ${ }^{21}$ from under seven puds ${ }^{22}$ dandy had put on the top of his head. His scalp was three tutum thick. His stubbly iron hairs looked like runt willow trees. He put on his hands mittens, weighing five puds. He did not even take them off, they fit him without a wrinkle. He put on his shins boots, weighing thirty puds. His coat could easily cover the half of the sky. His waistcoat could cover the whole half of the earth. His trousers fit his legs tightly, his deer skin shirt wrapped his body.

One last and important remark on the image of bogatyrs in Yakut olonkho: both the good and the evil forces are called bogatyrs due to the fact that they have special extraordinary or supernatural powers which make them different from and more superior than typical human beings. While the antagonists in Russian bylinas normally attain an animalistic form, the Yakut olonkho chthonic characters may or may not necessarily resemble animalistic creatures, however, in most cases, both antagonists and protagonists in olonkho have the animorphic abilities. Protagonists usually resemble human beings with extraordinary powers (on the analogy with the Russian bogatyrs). Antagonists or chthonic characters most commonly resemble monstrous, highly unattractive and unpleasant creatures.

\section{Conclusion}

The present article provided a concise overview of the main approaches to the definition of folklore and to its subgenres of oral (vocal art). It also gave a brief overview of the history of bylinas and olonkho and an explanation of the existing differences and similarities of the two genres. The study revealed that they are the same in their literary concept but somewhat different 
in their semantic content when it comes to the images of the bogatyrs. One of the main findings is that "bogatyr" is a word which in the Yakut tradition is used to refer to any kind of creature (human or non-human) that has some kind of superpower. While, in the Russian tradition, the word is mainly used to refer to the protagonists of the bylinas. Antagonists are normally referred to by a specific negative name or by the features that they possess. Most commonly, it is an allegory of the tribes that used to attack the territory of Ancient Rus'. In case of the Yakut olonkho, the evil forces ascend into the Middle World from the Under World and unsuccessfully try to cause harm to the main character and his/her family. In Russian bylinas, it is implied that the forces of evil originate from the Under World, but it is not mentioned explicitly.

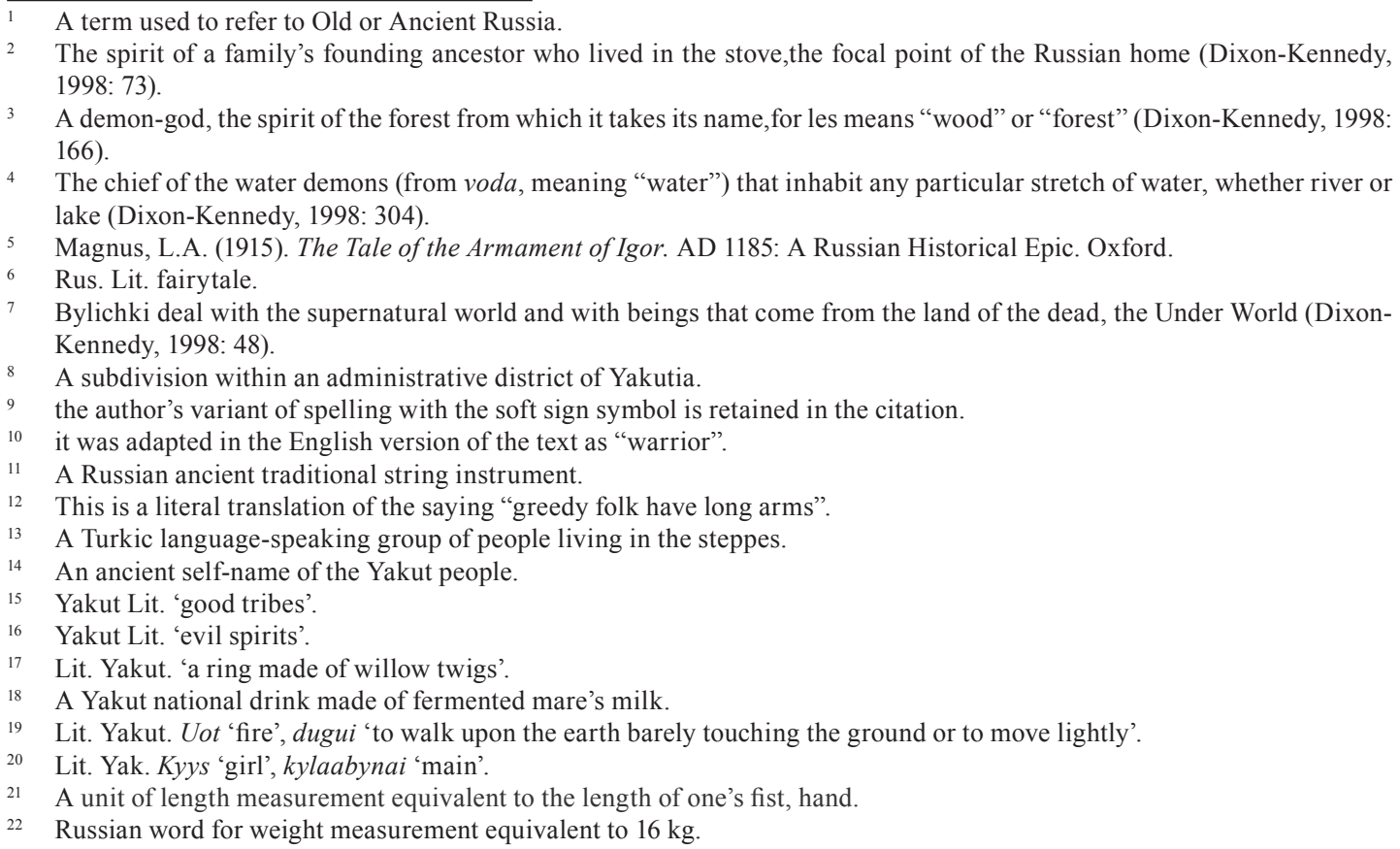

\section{References}

Anikin, V.P. (2004). Russkoye ustnoye narodnoye tvorchestvo [Russian traditional oral art]. $2^{\text {nd }}$ ed., Moscow: Vyshaya Shkola, 735 p.

Dixon-Kennedy, Mike. (1998). The Encyclopedia of Russian and Slavic Myth and Legend. Library of Congress Cataloging-in-Publication Data. Santa Barbara, California; Denver, Colorado; Oxford, England, 375 p.

Illarionov, V.V. (2016). Epicheskoye naslediye naroda Sakha [Epic heritage of the Sakha people]. Novosibirsk: Nauka Press, 344 p.

Illarionov, V.V. (2006). Yakutskoye skazitel'stvo i problem vozrozhdeniya olonkho [Yakut intangible art and the problems of restoring theolonkho tradition]. Novosibirsk: Nauka Press, $191 \mathrm{p}$.

Kaspari, A. (1894). Russkiye byliny i skazaniya, Kievskiy period [Russian bylinas and folktales, the Kievan period] - a collection. St. Petersburg, Rodina Press, 104 p.

Karataev, V.O. (2017). Ogo Tulaaiakh Warrior. English translation by V.K. Neustroeva. Yakutsk: Alaas Publishing, $232 \mathrm{p}$. 
Karnaukhova, G. (2003). Russkiye bogatyry. Byliny. Geroicheskiye skazki: Detskaya literature [Russian bogatyrs. Bylinas. Heroic fairytales: children's literature]. Moscow.

Krukova, M.S. (1938). Slava Stalinu budet vechnaya [Stalin's glory will be remembered forever], in Tvorchestvo narodov SSSR [Poetry of the USSR peoples] Moscow.

Meletinsky, E.M. (1990). Mifologichesky slovar [A Dictionary of Mythology]. Moscow: Sovietskaya Entsiklopedia Press, 672 p.

Propp, V. (1984). Theory and History of Folklore. Translated by Ariadna Y. Martin and Richard

P. Martin et al. Edited, with an Introduction and Notes by Anatoly Liberman. Theory and History of Literature, Volume 5. University of Minnesota Press, Minneapolis.

Putilov, B.N. (1994). Folklor i narodnaya kultura [Folklore and traditional culture]. St.Petersburg, Nauka Publishing.

Ryabina-Andreeva, P.I. (1940). Byliny [Bylinas]. Petrozavodsk, pp. 109-114.

Tomskaya-Chaaika, D.A. (2016). Kyys Kylaabynai the Warrior. English translation by V.K. Neustroeva. Yakutsk: Alaas Publishing, 240 p.

\section{Образ богатырей в якутских и русских фольклорных текстах}

Е.В. Наумова

Северо-Восточный федеральный университет им. М.К. Аммосова Россия, 677000, Якутск, ул. Белинского, 58

Практически во всех развитых мировых культурах присутствуют письменные или устные памятники древней культуры, созданные людьми, а точнее представителями определенной народности или нации. Возможно, в некоторых случаях эти памятники не были признаны широкой публикой по тем или иным отдельным причинам. Однако в некоторых случаях эти устные образиы творчества дошли до нас благодаря тому факту, что они были воспроизведены и обрели письменную форму. Таким образом, любой, кто желает узнать о фольклоре или фольклорных традиџия той или иной национальной группы, может сделать это без каких-либо затруднений, особенно сейчас, когда многие из этих уникальных образцов культуры были переведены с исходного языка на другие. В данной статье основное внимание уделяется литературоведческому анализу выдающихся героев русского и якутского фольклора с иелью выяснить, какие аспекты, если таковы есть, влияют на отражение сути этих персонажей и совпадает ли понимание понятия «богатырь» в обеих культурах с лингвистической, семантической и идеологической точками зрения.

Ключевые слова: фольклор, русские былины, якутское олонхо, богатыри, традиции, антагонисты, протагонистыл.

Научная специальность: 10.02.00 - лингвистика, 24.00.00 - культурология. 